УДК 159.955.2

https://doi.org/10.52058/2708-7530-2021-11(17)-364-376

Губенко Олександр Володимирович доктор психологічних наук, старший науковий співробітник, Інститут психології імені Г.С. Костюка НАПН України, вул. Панківська 2, м. Київ, 01033, тел.: (044) 288-33-20, https://orcid.org/0000-0002-7197-3913

Циганчук Тетяна Володимирівна кандидат психологічних наук, доцент кафедри практичної психології, Київський університет імені Бориса Гринченка, бульв. І.Шамо, 18/2, м. Київ, 04053, тел.: (095) 674-74-38, e-mail: t.tsyhanchuk@gmail.com, https://orcid.org/0000-0003-0699-4395

\title{
ПРОБЛЕМА МОДЕЛЮВАННЯ ПРОЦЕССІВ ОПЕРАЦІОНАЛІЗАЦІЇ ПСИХОЛОГІЧНОГО ЗНАННЯ
}

Анотація. В статті досліджено й проаналізовано особливості мови психологічної науки. Запропоновано формальну модель, яка б дозволила передати специфічні особливості мови психологічної науки.

Для вирішення мети дослідження використані процедури аналізу й моделювання мови науки. Для цього були залучені природничо-наукові аналогії, зокрема, математична модель так званої «складки Уітні».

Визначено, що психологія знаходиться на перетині гуманітарної та природничої сфер пізнання. В психологічних дослідженнях перед дослідниками постає складний парадокс наукової мови. Даний парадокс визначається питанням, яким чином однозначною мовою математики описати багатозначні гуманітарні категорії й концепти. Працюючи над розв'язанням зазначеного парадоксу, ми розробили математичний підхід до моделювання багатозначних семантик за допомогою однозначних математичних кодів. Цей підхід спирався на математичну теорію катастроф.

Нам вдалося представити такі складні й багатозначні явища як гуманітарний та природничо-науковий інтелект у вигляді топологічної моделі. Модель спирається на топологічну «складку Уітні». Вона містить однобагатозначні відповідності між знаком (поняттям) й його змістом. В якості об’єкту моделювання виступала одиниця сенсу, яку ми назвали семантичною згорткою.

Семантичні згортки були поділені на однозначні (моносемантичні) й багатозначні (полісемантичні). Перші розглядалися як основні одиниці мови природничих наук та раціонально-логічного мислення, яке складає їхню основу; другі - як основні одиниці гуманітарних наук та інтуїтивного мислення, яке лежить в їхньому підгрунті. 
Топологічна модель наукового мислення, яку було створено, дозволила дати математичну інтерпретацію складних одно-багатозначних смислових механізмів у процесі науково-психологічного пізнання.

Ключові слова: гуманітарні науки; моделювання; мова психологічної науки; природничі науки; операціоналізація; теорія катастроф.

Gubenko Oleksandr Volodymyrovych Doctor of Psychological Sciences, Senior Research Officer, G.S. Kostiuk Institute of Psychology of the National Academy of Pedagogical Sciences of Ukraine, 2, Pankivska St., 2, Kyiv, 01033, tel.: (044) 288-33-20, https://orcid.org/0000-0002-7197-3913

Tsyhanchuk Tetiana Volodymyrivna PhD in Psychology, Associate Professor at the Department of Practical Psychology, Borys Grinchenko Kyiv University, Ihor Shamo Blvd, 18/2, Kyiv, 04053, tel.: (095) 674-74-38, e-mail: t.tsyhanchuk@gmail.com, https://orcid.org/0000-0003-0699-4395

\section{THE PROBLEM OF SIMULATION OF PROCESSES OF OPERATIONALIZATION OF PSYCHOLOGICAL KNOWLEDGE}

Abstract. The article presents the results of a theoretical analysis of the phenomenon language of the psychological science. The purpose of the study is to propose a formal model that would allow to convey the specific features of the language of psychological science.

Procedures for analysis and modeling of the language of science were used to solve the research problems. For this purpose, natural science analogies were used, in particular, the mathematical model of the so-called "Whitney folds". It has been found that psychology is at the intersection of the humanities and the natural spheres of knowledge In psychological research there is a complex paradox of scientific language. It sounds like this: how to describe ambiguous humanities categories and concepts in the unambiguous language of mathematics.

Working to solve this paradox, we have developed a mathematical approach to modeling multivalued semantics using unambiguous mathematical codes. This approach was based on the mathematical theory of catastrophes. We were able to present such complex and multifaceted phenomena as the humanities and natural sciences in the form of a topological model. The model is based on the topological "Whitney fold". It contains unambiguous-multifaceted correspondences between a sign (concept) and its content. The object of modeling was a unit of meaning, which we called a semantic convolution.

Semantic convolutions were divided into unambiguous (monosemantic convolutions) and multivalued (polysemantic). The first were considered as the basic units of the language of the natural sciences and the rational-logical thinking that underlies them, the second - as the basic units of the humanities and the intuitive 
thinking that underlies them.

The topological model of scientific thinking, which was created, allowed to give a mathematical interpretation of complex unambiguous-multifaceted semantic mechanisms in the process of scientific and psychological cognition.

Keywords: humanities; modeling; the language of psychological science; natural sciences; operationalization; catastrophe theory.

Постановка проблеми. Дослідження проблеми операціоналізації наукових категорій та мови наукової теорії $є$ одним 3 найважливіших завдань методологічного аналізу. Операціоналізація, як відомо, - це пізнавальна процедура аналітичного «розщеплення» нечітких багатозначних понять 3 метою створення системи однозначних чітких значень і понять, які піддаються вимірюванню для ретельного вивчення багатозначних теоретичних концепцій й складних явищ об'єктивної дійсності.

Ми надаємо цьому слову традиційного значення, згідно 3 яким операціоналізація (англ. Operationalization) - перетворення теоретичного судження $з$ метою його емпіричної перевірки. Наприклад, для будь-якого явища повинні бути визначені властивості, що характеризують його зміст (так звані «індикатори»). На основі виділення та визначення властивостей повинні бути запропоновані процедури їх вимірювання. Процедура операціоналізації дозволяє отримати більш строгі визначення для тих теоретичних понять, яким властиві нечіткість, синтетичність, неконкретність.

Вважається, що таким чином теорія стає на твердий грунт експериментів і спостережень, позбавляється ознак суб'єктивізму, набуває статусу об'єктивності та веріфікується.

Але, як нам здається, є необхідність в подальшому аналізі цієї категорії щодо обох основних галузей наукового знання - гуманітарного i природничого, який би дозволив вийти за рамки традиційних алгоритмів i моделей розуміння цілісного процесу наукового пізнання.

Перехід до посткласичних уявлень про операціоналізацію $є$ тим більш актуальним, що класичні уявлення про чіткість понять були витіснені з науки принципом невизначеності Гейзенберга та ймовірнісним підходом квантової механіки.

У зв'язку з цим хочемо звернути увагу на особливу складність та неоднозначність проблеми визначення й операціоналізації категорій саме психологічного знання. Гуманітарна мова в цілому, у порівнянні із природничо-науковою, більш багатозначна, менш визначена, чітка i точна. Такі психологічні поняття, як особистість, інтуїція, творчий інтелект та багато інших, і як результат, сам концепт психологічного знання, не піддаються однозначному трактуванню.

Аналіз останніх досліджень і публікацій. Як ми вже зазначали, в гуманітарних науках в цілому і в психології, зокрема, існує низка категорій, понять і концепцій, які відзначаються багатозначністю й невизначеністю свого 
змісту. Таких, наприклад, як ідеальне, реальність, інтуїція, буття, добро і зло, прекрасне і потворне тощо. С такі поняття не тільки в гуманітарних науках психології, філософії, соціології та інших, але й в так званих точних.

В математиці, наприклад, таким статусом невизначеності точного змісту володіє математична крапка. Вона визначається, як об’єкт, який не має виміру, але в такому випадку залишається незрозумілим, яким чином 3 того, що не має виміру, складаються багатовимірні геометричні об'єкти? Як зазначав у цьому зв’язку видатний французський математик Ніколя Бурбакі (псевдонім, за яким стоїть група францізських математиків): «Від елеатів до Больцано і Кантора математики i філософи не в силах були розв'язати парадокс - як кінцева величина може складатися 3 нескінченного числа точок, які не мають розміру...» [7].

У фізиці такими об’єктами є елементарні частинки (якщо їх відкрито більше 600, то які ж вони елементарні?), фізичне поле - одна з головних

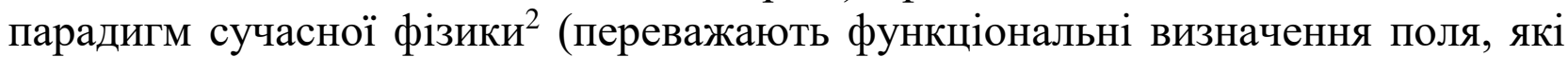
дозволяють працювати із цим поняттям, але не пояснюють його природу ${ }^{3}$ ), квантова суперпозиція, квантова невизначеність ${ }^{4}$ тощо. Як бачимо, точність в «точних» науках теж поняття відносне.

Ми хочемо звернути увагу на кілька важливих моментів, які споріднюють згадані поняття із гуманітарними категоріями. Серед цих моментів: статус природничо-наукових категорій як проблемних зон, які, тим не менш, використовуються так, немов би проблеми немає; неточність і багатозначність «точних» понять, які схоплюються мисленням не на раціональному, а на інтуїтивному рівні. Із зазначеними фізико-математичними поняттями відбувається теж саме, як із деякими гуманітарними категоріями: вони не піддаються операціоналізації.

\section{Мета та завдання дослідження:}

1. Вивчити й проаналізувати специфіку наукової мови, й, зокрема, мови психологічної науки.

2 «Польова парадигма, що представляє всю фізичну реальність...є не тільки однією 3 найважливіших в сучасній фізиці, але, мабуть, безумовно головною» (Див.: Wikipedia / Поле (физическое).

${ }^{3}$ У визначеннях природи поля фізики не можуть сказати щось певне, крім аналогій, і ось характерний зразок такого визначення: «Найпростіше наочно уявити собі поле як збурення (відхилення від рівноваги, рух) деякого (гіпотетичного або просто уявного) суцільного середовища, що заповнює весь простір. Наприклад, як деформацію пружного середовища.... Що це за середовище, яка природа цього середовища - носія фізичного поля - не уточнюється, бо це невідомо...(Див.: Wikipedia / Поле (физическое)

4 Теж саме - $\epsilon$ функціональні визначення, але вони не пояснюють природу явища. Існує більше десятка інтерпретацій квантової невизначеності. 
2. Запропонувати формальну динамічну модель, яка 6 дозволила репрезентувати механізми функціонування мови науки та специфічні риси мови психологічного знання, іiі нечіткість та багатозначність.

Для вирішення поставлених завдань в нашому дослідженні використані процедури аналізу й моделювання мови науки із залученням природничонаукових моделей і аналогій, зокрема, топологічної моделі, так званої «складки Уітні» із арсеналу «математичної теорії катастроф» - порівняно нової галузі математики, яка моделює неврівноважені стрибкоподібні природні процеси.

Виклад основного матеріалу. В нашому дослідженні ми зупинимось на проблемі операціоналізації ключового явища для розуміння полісемії наукової мови - самого феномену багатозначності засобів репрезентації знання.

Полісемічність гуманітарних категорій та проблема їхньої операціоналізації засобами точних наук. Важливий аспект проблеми операціоналізації наукового знання - це порівняльний аналіз як природничонаукової, так i гуманітарної методологічних традицій. Він дозволяє відзначити, що, при спільній налаштованості на пізнання дійсності, вони розрізняються наданням переваги у першому випадку точності й доказовості отримуваних знань, а у другому повноті охоплення властивостей складних об'єктів.

Точність досягається завдяки однозначності й чіткості природничонаукових понять; повнота охоплення об'єктів - за рахунок багатозначності, полісемантичності й відносній невизначеності категорій i понять гуманітарних.

Відомий український психолог Г.О. Балл, який аналізував ці дві сфери наукового пізнання, вважав, що слід визнавати цінність обох типів пізнання, зокрема, у психологічній науці. Але кожен з цих типів має свої обмеження й переваги.

Вчений відзначав принципову неоднозначність мови гуманітарних наук. «...У гуманітарній галузі, 3 огляду на складність й суперечливість досліджуваних об'єктів, виконання цієї вимоги (однозначності понять) наштовхується на великі труднощі» [4]. Далі він цитує Г.С. Померанца: «Порівнюючи в цьому плані різні галузі знання, Г.С. Померанц пише: «Точні науки ... мають справу із банальними предметами думки. Тому вони й точні. Можна точно висловитись про властивості міді, з органічними молекулами справа вже гірше... А з людиною зовсім погано. Спробуйте точно висловитись про Гамлета» [4].

На нашу думку, психологія не належить повністю ні до гуманітарних наук, ні до природничих, а знаходиться на перетині цих головних сфер пізнання, займає межове становище між ними. В психології перед дослідниками постає складний парадокс наукової мови: яким чином однозначною мовою математики описати багатозначні гуманітарні категорії й концепти. 
Цей парадокс існує в інших, не тільки в гуманітарних науках. Але в психології він виражений 3 особливою гостротою. Крім того, теза про необхідність тотальної математизації психології неправомірна, як, втім, й точка зору про домінування в психологічному знанні «чистого» теоретизування. Математизувати все психологічне знання неможливо за визначенням, як не можна математизувати мистецтво, поезію або філософію.

Компоненти суб'єктивізму, інтуїтивності, полісемантичності й авторської неповторності продукту творчості, які традиційно вважаються притаманними мистецтву, властиві, в тій чи інший мірі, й багатьом психологічним теоріям. Це не є ознакою неповноцінності психології як науки, а виступає природнім проявом психологічного знання, яке має, як ми вже зазначали, двоїсту природу.

Гуманітарна і природнича складові психології взаємодоповнюються, а не взаємовиключаються.

Принцип доповнювальності протилежних концепцій і теоретичних картин об’єкта, що породжує повноту знання про об’єкт прийшов в методологію із квантової фізики, в якій він був запропонований Н. Бором. Завдяки йому в квантовій фізиці вдалося примирити хвильову й корпускулярну теорії квантів.

Протиріччя, замість того, щоб його виключити 3 картини квантової реальності, було покладене в основу іiі природи. Таким чином, на нашу думку, слід вчинити i в психології, i покласти двоїсту гуманітарно-природничу природу психологічного знання в основу науки про душу.

Стару суперечку між позитивістським і гуманітарним підходом, між «фізиками» та «ліриками» неможливо розв’язати на користь лише однієї із сторон. Важлива і математика, і експеримент, i теоретичні узагальнення, i споглядальні знання. Експеримент неможливий без функціональної теорії, оскільки «тільки теорія вирішує, які саме факти можна спостерігати» (відома думка А. Ейнштейна, висловлена у розмові із В. Гейзенбергом) [8]. Теорія, 3 іншого боку, грунтується на фактах і $є$ інструментом їхньої інтерпретації та розуміння.

Виникає проблема співвідношення емпіричного та теоретичного, апріорного та апостеріорного. Ці компоненти пізнання при найближчому розгляді утворюють замкнене коло: факти спостерігаються завдяки теорії, теорія виникає завдяки фактам. Цей парадокс неможливо розв’язати шляхом застосування апарату однозначних логічних умовиводів (мови природничих наук).. Це демонструє, наскільки недостатньою є природничо-наукова мова з їі намаганням описати багатозначні об’єкти пізнання однозначними категоріями.

Простежимо ланцюжок умовиводів, що породжує дане замкнене коло.

Емпіричне пізнання опосередковується теоретичним. Теоретичне пізнання визначає, які саме явища та події мають бути об'єктом емпіричного дослідження, які параметри об’єкта необхідно виміряти і в яких умовах слід здійснювати експеримент. Проте, теорія повинна грунтуватися на 
встановлених і перевірених фактах та передбачати можливість перевірки за допомогою експерименту. Тобто, вона будується на основі фактів, створюється як їхнє узагальнення.

Таким чином, виникає парадокс співідношення теоретичного та емпіричного в пізнанні: 1) тільки теорія вирішує, які факти можна спостерігати. Тобто факти віднаходяться, спостерігаються й розуміються через призму теорії. 2) Теорія виникає як узагальнення фактів. Тобто теорія віднаходиться й будується на основі фактів. Замкнене коло в умовиводах: факти спостерігаються завдяки теорії, теорія виникає завдяки фактам. Що розв’язує цю антиномію й розмикає це логічне коло?

Як бачимо, однозначної семантики логчного пізнання недостатньо. Вирішення даного парадоксу стає можливим за допомогою інтуїтивного знання, яке має своїм підгрунтям багатозначну семантику. I колізії співвідношення теоретичного та експериментального рівнів пізнання можна вирішувати спираючись саме на інтуїтивне мислення.

Відповідно, описати багатозначний об'єкт пізнання в мові когнитивних репрезентацій можна кількома засобами:

1) багатозначною мовою гуманітарних наук, але такий опис виходить нечітким, занадто невизначеним;

2) однозначними категоріями «точних» наук. Опис виходить достатньо чітким; наратив - достатньо логічно проробленим. Але вони не дають повної картини об'єкту. Їм не вистачає багатобічності, гнучкості, синтезу суперечливих характеристик.

Також при описі багатозначних об'єктів однозначною мовою природничих наук виникають певні невирішувані протиріччя і парадокси, зокрема ті, що ми вже описували: парадокс принципової неможливості вираження многозначного об'єкту пізнання через однозначну мову «точних» наук та однозначну семантику раціонально-логічного дискурсу; парадокс «замкненого кола» у співвідношенні теоретичного та емпіричного в пізнанні;

3) одним із історично відомих шляхів вирішення цих парадоксів $\epsilon$ поєднання в описі об’єкта двох суперечливих систем однозначного опису, за рахунок чого досягається багатозначність (цей аспект знайшов вираз в принципі доповнювальності Н.Бора);

4) шляхом інтуїтивного мислення, яке спирається в самій своїй основі на багатозначність семантики та на парадоксальність й поєднання протилежностей [10]. Але інтуїтивні осяяня, відрізняючись глибиною, не відрізняються чіткістю.

5) як певний компроміс між чіткістю однозначних когнітивних репрезентацій та нечіткістю багатозначних та між формальністю математичних методів та інтуїтивностю гуманітарних методів на протязі 20 ст. виникли кілька нових напрямів в логіці та математиці - нечіткі логіки (так звані фуцці-логіки) та інтуїционістька математика. 
За словами В. Ф. Асмуса, «інтуїционізм надав переконливі докази неможливості чисто формалістичного обгрунтування математики, довів необхідність змістовної математики... Інтуїціоністи довели, що для доказу несуперечливості потрібне застосування повної індукції, повна ж індукція спирається на інтуїцію...» [2]. А. Пуанкере вважав, що в математичній творчості головну роль грає інтуїція, а логіці відведена роль обгрунтування інтуїтивних прозрінь. (Звернемо увагу, у Пуанкаре йдеться про найбільш заформалізовану і «логічну» науку - математику, і якщо вже в математиці, на думку одного 3 найвидатніших математиків в історії, формально-логічні процедури є вторинними під час пошуку нових рішень, що говорити про інші науки, особливо гуманітарні й, зокрема, психологію!). Визначене бачення математичної творчості описано в книгах «Наука и гіпотеза» (1902) та «Наука і метод» (1908) [15].

Ідея "Fuzzy-Logic" (Фуцці-логіки), що в перекладі з англійської мови означає нечітка, розмита логіка, полягала в тому, що людський спосіб міркувань, що спирається на природню мову, не може бути описаний в рамках математичних формалізмів (див: (Архангельський, Богаєнко, Грабовський, Рюмшин, 1997). Людина міркує не формулами, а нечіткими поняттями. Тому була запропонована нова математична дисципліна, в основі якої лежала б теорія "нечітких множин "(Fuzzy Sets).

Грунтуючись на принципі нечіткості, можна створити формальний апарат для моделювання людських міркувань і людського способу мислення.

Із полісемантичності гуманітарного знання 3 необхідністю витікає феномен плюралістичності теорій, які пояснюють психологічні явища. Загальновідомо, що існує багато теорій, які інтерпретують природу особистості, інтелекту, емоцій, пам'яті тощо.

Зрозумілим є той факт, що багатозначність мови науки - явище не випадкове, а пов'язане із багатством та різноманітністю самої реальності. Тому не здаватиметься такою вже парадоксальною думка, що багатозначність наукових понять - це не прояв їхньої недосконалості, а, навпаки, їхня перевага, яка допомагає охоплювати складні і невизначені об’єкти пізнання. Саме на цьому (складність об'єкта психологічного знання і складність психологічної мови у порівнянні із більш однозначною мовою фізики) наголошував Ейнштейн у розмові із Ж. Піаже, в якій констатував, що психологія набагато складніше фізики [12].

Тому в ряді випадків варто не заганяти гуманітарно-теоретичні форми пізнання в прокрустове ложе однозначних формалізмів, а визнавати неминучість і виправданість їхньої присутності в наукових теоріях. I не тільки в гуманітарних, а і в природничих.

Тим більше, що сучасні так звані «точні науки» - фізика, математична 
логіка, теорія систем, синергетика - демонструють численні приклади плюралістичної інтерпретації природніх феноменів. Одних тільки інтерпретацій квантової механіки існує більше десяти - найбільш поширених чотири (Копенгагенська інтерпретація, багатосвітова інтерпретація Еверетта, «Ніяка» інтерпретація, Інтерпретація фон Неймана - Вігнера), та малопоширеніх більше шести (Теорія де Бройля - Бома, Інтерпретація Блохінцева, Об'єктивна редукція, Транзакційна інтерпретація тощо).. Можливо, «точні науки» - не такі й вже точні, як вважається. Хоча це не заважає деяким із «фізиків» продовжувати зверхньо і зарозуміло ставитися до «ліриків», займаючи щодо гуманітаріїв позицію своєрідного природничонаукового шовінізму.

Працюючи над розв'язанням зазначених парадоксів, вчені витрачали велики зусилля. Ми теж зробили спробу розробити математичний підхід до моделювання багатозначних семантик за допомогою однозначних математичних кодів [11].

Наш підхід спирався на математичну теорію - так звану математичну теорію катастроф [1]. Нам вдалося представити такі складні й багатозначні явища як гуманітарний та природничо-науковий інтелект у вигляді топологічної моделі, яка виходить з так званої топологічної «складки Уітні» [1] і містить однобагатозначні відповідності між функцією й аргументом. В якості функції розглядався семантичний континуум мислення, а аргументом виступала одиниця сенсу, яку ми назвали семантичною згорткою.

Семантичні згортки були поділені на однозначні (моносемантичні згортки) й багатозначні (полісемантичні). Перші розглядалися як основні одиниці мови природничих наук та раціонально-логічного мислення, яке складає їхню основу, другі - як основні одиниці гуманітарних наук та творчого інтуїтивного мислення, яке лежить їхньому підгрунті.

У моносемантичних згорток спостерігалася однозначна відповідність між сигніфікатом і денотатом (ця особливість характерна для «точних» наук), у полісемантичних - неоднозначна (одно-багатозначна), коли символу відповідають не одне, а кілька значень поняття, яке представлене у даному символі (особливість, яка притаманна мові гуманітарних наук). Дана топологічна модель наукового мислення, яка дозволяє дати математичну інтерпретацію складних одно-багатозначних смислових механізмів у процесі науково-психологічного пізнання представлена на рис.1 [18]. 


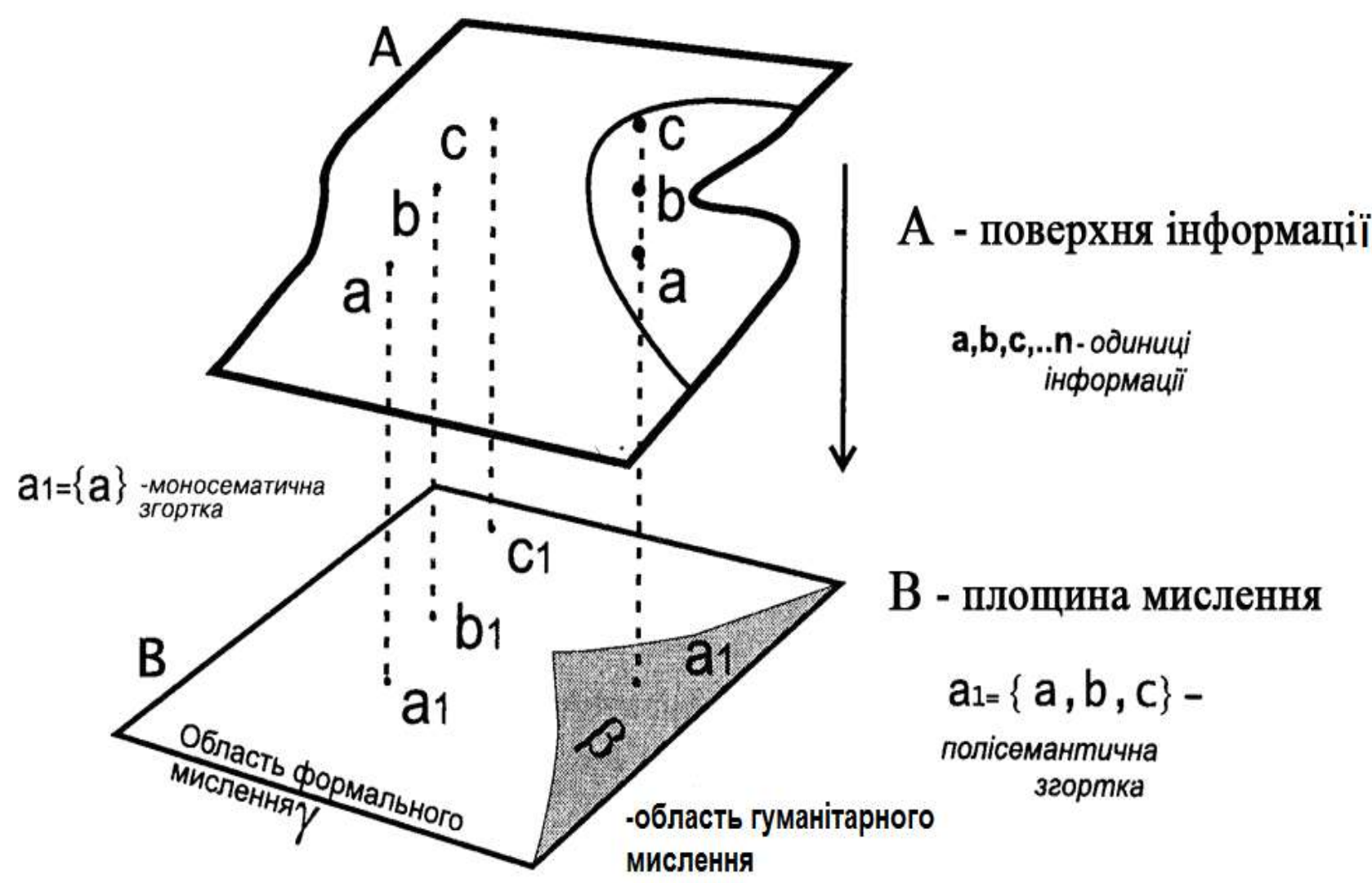

Примітка: А - поверхня інформації; а, в, с... n - одиниці смислової інформації; В - площина мислення; A $\{\mathrm{a}\}$ - моносемантична згортка; $\gamma$ область формального природничо-наукового мислення; $\beta-$ область інтуїтивного гуманітарного мислення; точка a1 $\{a\}$ на площині $\gamma$ моносемантична згортка; точка al $\{\mathrm{a}, \mathrm{B}, \mathrm{c}\}$ на площині $\beta$ - полісемантична згортка.

Pис.1. Топологічна модель наукового мислення.

Розглянемо перехід від полісемантичних згорток до моносемантичних, тобто від мови гуманітарних наук до мови природничих, або до дискурсивнологічного формального мислення.

Взаємодія смислів в гуманітарному мисленні має синтетичноконтинуальний характер завдяки «ворушінню» (або флуктуаціям) площини інформації у нашій моделі. Внаслідок цього відбувається «накладання» та «змішування» змістів.

Аналітичне «розділення», «дифракція» змістів, перетворення синтетичних, багатозначних та невизначених гуманітарно-інтуїтивних смислів у аналітичні, однозначні висловлювання та судження, властиві природничонауковому мисленню, - відбувається в нашій моделі внаслідок розгладжування площини інформації. Багатозначні поняття, туманні ідеї та 
категорії гуманітарного знання моделюються за допомогою флуктуацій «поверхні інформації» (А).

Вона приймає складкоподібну форму, й проектує точки-смислів (a, в, с) на площину мислення В, відповідно, утворюючи багатозначні гуманітарні поняття типу a1 $\{\mathrm{a}, \mathrm{B}, \mathrm{c}\}$ (знак фігурних дужок $\{\mathrm{a}, \mathrm{B}, \mathrm{c}\}$ означає, що поняття a1 містить в собі множину понять a, в, с). Множина таких багатозначних понять (вони є полісемантичними згортками) утворює сектор гуманітарного мислення $\beta$ на площині мислення В.

Під час переходу від флуктуацій до «розгладжування» інформаційного поля точки смислу перестають накладатися одна на одну, проектуються в однозначні точки на площині мислення, які моделюють моносемантичні згортки, й перетворюються в систему аналітичних однозначних й чітких суджень, пов'язаних між собою всіма правилами логіки, як це властиво для природничого знання.

На мові психосемантики цей процес описується як перехід мислення від функціонування в режимі полісемантичних згорток (режимі гуманітарного мислення) до функціонування в режимі моносемантики (режимі точного мислення).

Отже, семантика наукової мови функціонує у двох станах континуальному та дискретному. Континуальний стан визначає гуманітарні категорії і поняття з їх інтуїтивним або напівінтуїтивним режимом існування, дискретний - природничо-наукові 3 їх, переважно, моносемантичним дискурсивно-логічним режимом існування. За таким алгоритмом здійснюється динаміка операціоналізації наукового мислення.

Дискусія. Пропонований математико-моделюючий підхід, як нам здається, дозволяє краще зрозуміти природу розбіжностей між гуманітарними та природничо-науковими інтерпретаціями дійсності, а також зробити ряд припущень, зокрема таких: гуманітарне знання $\epsilon$ не допоміжним щодо «точного» етапом пізнання, як прийнято вважати, а, в ряді випадків, основним. Невизначеність та багатозначність лінгво - семантичних засобів гуманітарної мови, хоча й несе певні незручності, але є ознакою іiі багатства й насиченості. Гуманітарно-психологічне знання спирається не тільки на формальні засоби точних наук, але й змістовні засоби інтуїції. Перспективою дослідження $\epsilon$ застосування математичних моделей функціонування знання до інших багатозначних психологічних явищ, зокрема, одного з найбільш багатозначних - до інтуїції.

Висновки. В статті запропонована топологічна модель механізмів взаємодії двох типів наукової мови і мислення - гуманітарного й природничонаукового. Вона може бути корисним методологічним інструментом для розуміння процесів операціоналізації багатозначних психосемантичних феноменів гуманітарно-психологічного знання. 


\section{Лimepamypa:}

1. Арнольд В.Н. Теория катастроф. М.: Наука, 1990. 127 с.

2. Асмус В.Ф. Проблема интуиции в философии и математике. (Очерк истории: xv11 - начало хх в.). Изд. 2-е. М.: Мысль, 1965. 312 с.

3. Архангельський B.I. та ін. Системи фуцці-керування / B.I. Архангельський, I.М. Богаєнко, Г.Г. Грабовський, М.О. Рюмшин. К.: Техніка, 1990. 208 с.

4. Балл Г.А. Наука как специфическая подсистема культуры в контексте диалогического похода в образовании / Г.А. Балл // Психология в рациогуманистической перспективе: Избранные работы. К.: Изд. «Основа», 2006. 480с.

5. Балл Г.О., Мединцев В.А. Теоретико-множественный метод описания процессов и его применение в психологи. Київ, 2016. 215с.

6. Бунге М. Интуиция и наука. Москва, 1967. 275 с.

7. Бурбаки Николя. Архитектура математики. Очерки по истории математики. М.: Иностранная литература, 1963.

8. Гейзенберг В.. Физика и философия. Часть и целое. Пер. с нем. М.: Наука. Гл. ред. физ.-мат. лит., 1989. 400 с.

9. Губенко А.В.. Феномен интуиции и интелектуальное творчество. Практична психологія та соціальна робота, 1999. № 8, С. 9-12.

10. Губенко О.В. До питання про біполярну природу творчого інтелекту. Практична психологія та соціальна робота, 2009. №6, С. 50-58.

11. Губенко А.В. Психологические проблемы творческой деятельности. (Интегративный подход): Монография / Губенко Александр Владимирович. К.: Издательство «Педагогична думка», 2018. 537 с.

12. Казакова Е.В. Психология: учебное пособие. Архангельск: Издательство «РАО», 2018. $237 \mathrm{c}$.

13. Кондаков Н.И. Логический словарь-справочник. М.: Наука, 1975. 520 с.

14. Пуанкаре А. О науке. М.: Наука. 1990. 736 с.

15. Пуанкаре А. Математическое открытие. М.: Изд-во МГУ, 1981.736 с.

\section{References:}

1. Arnold V. N. (1990). Teoriya katastrof [Catastrophe theory]. Moskva: Nauka [in Russian].

2. Asmus V. F. (1965). Problema intuitsii v filosofii i matematike [The problem of intuition in philosophy and mathematics]. Moskva: Mysl [in Russian].

3. Arhangelskiy V. I. (1997). Sistemi futstsI-keruvannya [Fuzzy control systems]. Kyiv: Tehnika [in Ukrainian].

4. Ball G. A. (2006). Nauka kak spetsificheskaya podsistema kulturyi v kontekste dialogicheskogo pohoda $\mathrm{v}$ obrazovanii [Science as a specific subsystem of culture in the context of a dialogical approach in education]. Kyev: Osnova [in Russian].

5. Ball G. O., \& Medintsev V. A. (2016) Teoretiko-mnozhestvennyiy metod opisaniya protsessov i ego primenenie $\mathrm{v}$ psihologi [The set-theoretical method for describing processes and its application in psychology]. Kyev [in Russian].

6. Bunge M. (1967). Intuitsiya i nauka [Intuition and Science]. Moskva [in Russian].

7. Burbaki Nikolya. (1963) Arhitektura matematiki. Ocherki po istorii matematiki [The architecture of mathematics. Essays on the history of mathematics]. Moskva: Inostrannaya literatura [in Russian].

8. Geyzenberg V. (1989). Fizika i filosofiya. Chast i tseloe [Physics and Philosophy. Part and whole]. Moskva: Nauka [in Russian].

9. Gubenko A. V. (1999). Fenomen intuitsii i intelektualnoe tvorchestvo [The phenomenon of intuition and intellectual creativity]. Praktichna psihologIya ta sotsIalna robota - Practical psychology and social work, 8, 9-12 [in Russian]. 
10. Gubenko O. V. (2009). Do pitannya pro bIpolyarnu prirodu tvorchogo Intelektu [Before eating about the bipolar nature of creative intelligence]. Praktichna psihologIya ta sotsIalna robota - Practical psychology and social work , 6, 50-58 [in Ukrainian].

11. Gubenko A. V. (2018). Psihologicheskie problemyi tvorcheskoy deyatelnosti. (Integrativnyiy podhod) [Psychological problems of creative activity. (Integrative approach)]. Kyev: Pedagogichna dumka [in Russian].

12. Kazakova E. V. (2018). Psihologiya: uchebnoe posobie [Psychology: textbook]. Arhangelsk: RAO [in Russian].

13. Kondakov N. I. (1975). Logicheskiy slovar-spravochnik [Logical dictionary-reference]. Moskva: Nauka [in Russian].

14. Puankare A. (1990). O nauke [About science]. Moskva: Nauka [in Russian].

15. Puankare A. (1981). Matematicheskoe otkryitie [Mathematical discovery]. Moskva: MGU [in Russian]. 